\title{
RELATIONSHIP BETWEEN BLUE CARBON AND METHANE AND THE HYDROCHEMISTRY OF MANGROVES IN SOUTHEAST MEXICO
}

\author{
AgraZ-Hernández, C. M. ${ }^{1}$ - CHAN-Keb, C. A. ${ }^{2^{*}}$ - MuÑIZ-SALAZAR, R. ${ }^{3}$ - PÉREZ-BALAN, R. \\ A. ${ }^{2}$ - Osti-SÁEnZ, J. ${ }^{1}$ - GutiÉRREZ-AlCÁNTARA, E. J. ${ }^{2}$ - REYES-CASTELlANO, J. E. ${ }^{1}$ - MAY- \\ COLLI, L. O. ${ }^{2}-$ CONDE-MEDINA, K. P. ${ }^{2}-$ RUIZ-HERNÁNDEZ, J. ${ }^{2}$ \\ ${ }^{1}$ Instituto EPOMEX, Universidad Autónoma de Campeche, Av. Agustín Melgar s/n entre Juan \\ de la Barrera y Calle 20, Col. Buenavista, A.P. 24039, San Francisco de Campeche, Campeche, \\ México \\ ${ }^{2}$ Facultad de Ciencias Químico Biológicas, Universidad Autónoma de Campeche, Avenida Ing. \\ Humberto Lanz Cárdenas S/N, Colonia Ex Hacienda Kalá, C.P. 24085 San Francisco de \\ Campeche, Campeche, México \\ ${ }^{3}$ Laboratorio de Epidemiología y Ecología Molecular, Escuela de Ciencias de la Salud, \\ Universidad Autónoma de Baja California, Blvd. Zertuche y Blvd. de los Lagos s/n. Fracc. \\ Valle Dorado C.P., Ensenada 22890, Baja California, México \\ ${ }^{*}$ Corresponding author \\ e-mail: carachan@uacam.mx; phone: +52-981-811-9800 (ext.2010110)
}

(Received 25 $5^{\text {th }}$ Jul 2019; accepted $4^{\text {th }}$ Dec 2019)

\begin{abstract}
The anthropogenic activities change hydrological pattern of mangrove ecosystems affecting their carbon accumulation and methane emissions. For this reason, the aim for this study was to estimate carbon and nitrogen quantity, in addition to methane emission associated with physicochemical parameters from sediment into three mangrove ecosystems (Los petenes Biosphere Reserve (BR), Laguna de Términos and Champotón) with different anthropic pressure and hydrological characteristics along the Campeche coast. Sampling was realized in rainy season and $\mathrm{pH}$, Redox from interstitial water were measured, soil parameters, salinity, methane emissions and carbon concentration were determined simultaneously. Carbon sequestered average in the three study areas was $170 \mathrm{Mg} \mathrm{ha}^{-1}$, significant differences were not observed $\left(\mathrm{F}_{2,29}=0.02, \mathrm{p}=0.97\right)$. The highest methane emissions were found in Laguna de Términos $\left(673.24 \pm 922 \mathrm{mg} \mathrm{m}^{-2} \mathrm{~h}^{-1}\right)$, with significant differences $\left(\mathrm{F}_{2,29}=3.55, \mathrm{p}=0.042\right)$ among the three ecosystems. Carbon sequestration in Los Petenes BR established an inverse relationship with methane emissions $\left(\mathrm{Y}=482.4-2.245 \mathrm{x}, \mathrm{R}^{2}=0.67, \mathrm{p}<0.025\right)$. In Champotón ecosystem, carbon sequestration presented a direct correlation with salinity $\left(\mathrm{Y}=-116.3+11.53 \mathrm{x}, \mathrm{R}^{2}=0.70, \mathrm{p}<0.008\right)$. Methane emissions in Laguna de Términos established an inverse relationship with soil $\mathrm{pH}\left(\mathrm{Y}=12027-2190 \mathrm{x}, \mathrm{R}^{2}=0.77, \mathrm{p}<0.0001\right)$, attributed to different environmental conditions and different prevailing anthropic pressures in each ecosystem.
\end{abstract}

Keywords: redox potential, soil, greenhouse gases, interstitial water, elemental analyzer, environment

\section{Introduction}

Globally, mangroves cover approximately 13,776,000 ha (Giri et al., 2011), with Mexico being one of the four countries with the largest mangroves of the 125 countries and territories in which this ecosystem is found, comprising an estimated cover of 770,057 ha (Rodríguez-Zúñiga et al., 2013). Mexico's mangrove forests are found in the watersheds of the Pacific, the Gulf of Mexico and the Gulf of California (Sandoval-Castro et al., 2014). The state of Campeche contains the largest area of mangroves in the country $(25.2 \%)$ (CONABIO, 2009). The mangroves on this coast are mainly located in the 
Laguna de Términos Flora and Fauna Protection Area, the Los Petenes Biosphere Reserve and on the Champotón river (Agraz-Hernández et al., 2015).

With the mangroves contributing a great variety of goods and services, they are considered one of the most productive ecosystems of the biosphere (Mazda et al., 1997; Barbier, 2008). They are characterized by functions of great ecological, economic and social value, providing diverse ecosystem services, such as protection against hurricanes and the mitigation of the erosion caused by winds and tides, while also functioning as natural barriers against marine currents and flooding (Alongi et al., 2004). In turn, the mangroves contribute to the retention of sediments and act as a deposit, as well as processing, recycling and exporting organic material and nutrients, and producing oxygen (Vázquez-Lule et al., 2019). Over the last 50 years, approximately a third of the world's mangrove forests has been lost due to anthropogenic activities, such as tourism, badly developed or unsustainable aquaculture, unmoderated industrial and urban development, highway construction, and unsustainable livestock and agricultural practices (Alongi, 2014).

The carbon stock is one of the most important ecosystem services provided by the mangroves, given that it contributes to minimizing the effects of climate change (Kauffman et al., 2013). The efficiency of a mangrove forest in capturing atmospheric $\mathrm{CO}_{2}$ mainly depends on its density and productivity, the basal area, height and age of the trees, and the photosynthetic efficiency of each species (Sitoe et al., 2014), which are, in turn, influenced by the physicochemical characteristics of the water and soil, the topography, the hydroperiod, the sediment dynamics and the climate. The carbon capture capacity of mangroves varies greatly on a global, regional and local level (Mitsch and Gosselink, 2000; De la Peña et al., 2010; Adame et al., 2013).

Alongi (2014) describes how the soil plays an important role in the carbon cycle, also mentioning that carbon sequestration in the mangrove forests occurs due to their low $\mathrm{pH}$ values, salinity concentration and hypoxic conditions, which contribute to the accumulation of carbon. However, soil use change caused by anthropogenic activities has negative effects on the carbon cycle, due to the modification of the decomposition rate of litterfall, sedimentation, the loss of plant biomass, and increased methane emission, causing more reduced conditions due to the decreased redox potential. This thus indicates the depletion of oxygen in the soil, an effect which occurs with greater intensity in the presence of the discharge of urban, agricultural, livestock and industrial waste water into the wetlands (Zinn et al., 2005; Lal, 2005). The mangrove wetlands do not efficiently accumulate carbon via photosynthesis, requiring a large amount of nitrogen-based nutrients, such as the nitrites and nitrates produced by the biogeochemical cycle. In this regard, Alongi et al. (2004) mention that the recycling of nutrients, such as nitrogen $(\mathrm{N})$ and carbon (C), in mangrove forests occurs via the decomposition of organic material through the production and defoliation of litterfall, for which reason, the concentration of nitrogen in the soil increases in line with carbon sequestration (Rivera-Monroy et al., 1995; Yimer et al., 2006).

The accumulation of nitrogen in the soil is also associated with the cover and the aerial plant biomass (Hooker and Compton, 2003; Liao, 2007).

The wetlands store carbon with a minimal release of greenhouse gases, due to the inhibition of methanogenesis by sulfates and salinity (Graham et al., 2005). However, various authors have demonstrated that the higher levels of nutrients of anthropic origin (eutrophication) found in mangrove forests generate higher methane emissions into the atmosphere by means of increased microbial activity (Kreuzwieser et al., 2003; Chen et 
al., 2010). Abril and Iversen (2002) report that, within marine systems, estuaries are an important source of methane emitted into the atmosphere as a consequence of the constant supply of nutrients of anthropogenic origin. Given the foregoing, the measurement of greenhouse gases $(\mathrm{GG})$, such as methane $\left(\mathrm{CH}_{4}\right)$ and nitrous oxide $\left(\mathrm{N}_{2} \mathrm{O}\right)$, in mangrove ecosystems has generated great interest, at both a global and national level (IPCC, 2001). For years, global estimates of wetland GG levels have been inaccurate, due to the lack of either flow measurements or an understanding of the environmental factors that control them (Lu et al., 1999). The objective of the present study was to estimate the amount of carbon, nitrogen and methane emissions in the soils of four mangrove forests along the length of the Campeche coast and presenting differences in environmental conditions and anthropic activity. It also seeks to relate the capture of carbon and nitrogen and methane emissions to the physicochemical variables of the soil during the rainy season.

\section{Material and methods}

\section{Study area and sample collection}

The geographical area studied here comprises the southeastern and northeastern parts of the state of Campeche and is divided into three zones: the Laguna de Términos (LT) Protected Natural Area, with two sampling sites (Xibujá and Atasta); Río Champotón (RC), with one site; and, Los Petenes Biosphere Reserve (RBP), with one site (Rio Verde) (Figures 1 and 2).

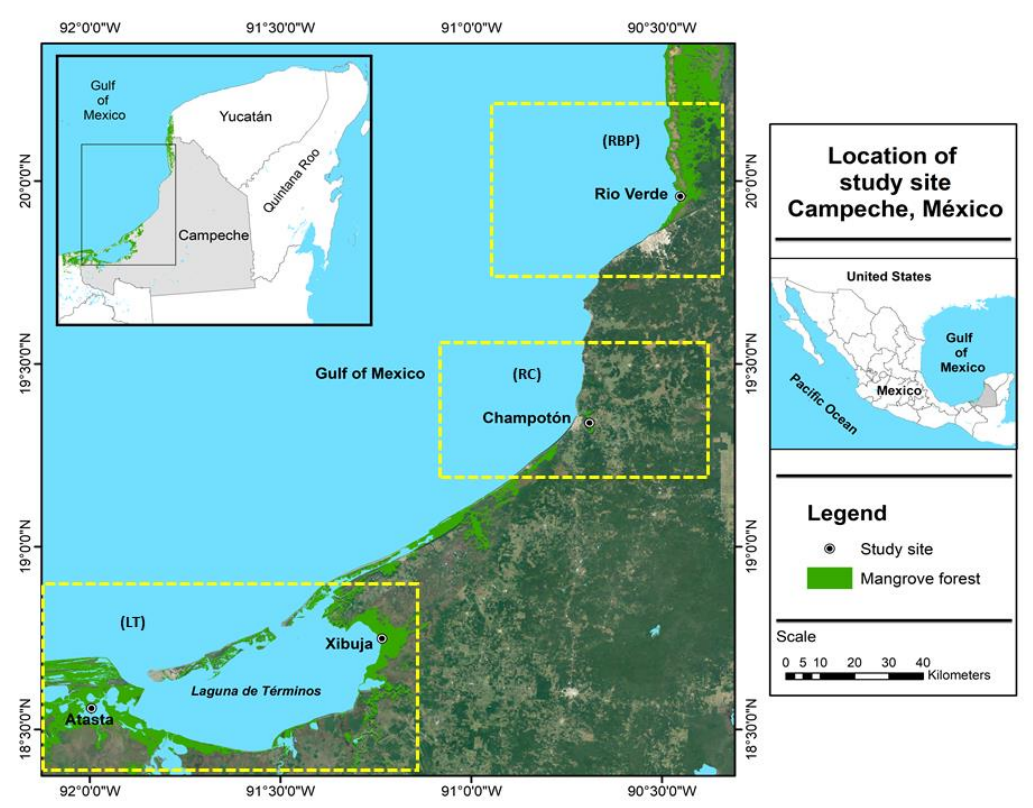

Figure 1. Geographical location established for three mangrove study areas in the southeast of Campeche: The Protected Natural Area Laguna de Términos (LT), Río Champotón (RC) and the Los Petenes Biosphere Reserve (RBP), Campeche

A sampling site was established within two plot of 0.01 hectares for each of three mangrove areas (RBP, RC and LT). Duplicate Samples of interstitial water and soil were obtained in each month of the rainy season (September and October, 2017) for every sampling site. 


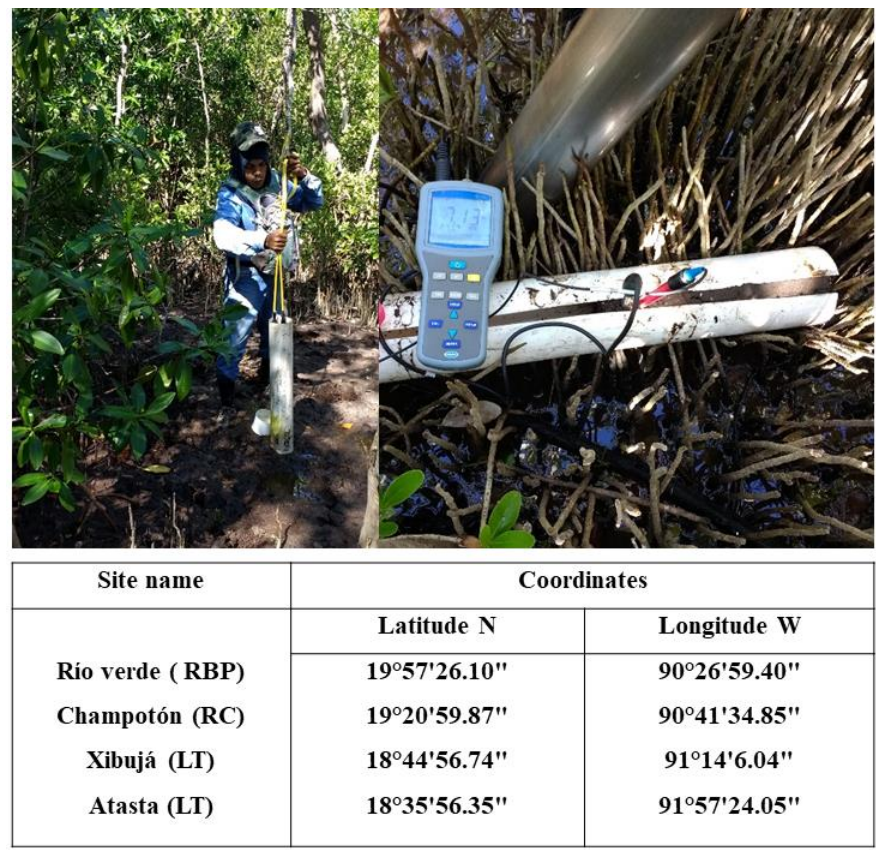

Figure 2. Measurement of the physicochemical parameters of the soil, interstitial water and sampling sites location

Located in the northern region of the state of Campeche, the Los Petenes Biosphere Reserve (Reserva de la Biósfera Los Petenes, or RBP) forms part of an ecoregion that includes the Ría Celestún Biosphere Reserve and the El Palmar Protected Natural Area in the state of Yucatán. These areas contain a high diversity of flora and fauna and unique ecosystems, particularly those found in Los Petenes and the seagrass beds, with the latter considered to be the largest in the country and in the best state of conservation. In 2004, the Los Petenes Biosphere Reserve was declared a RAMSAR site (named after the 1971 Ramsar Convention on Wetlands of International Importance especially as Waterfowl Habitat) in recognition of the peten (or hammock) ecosystems (complex habitats that develop as islands of varied vegetation). These ecosystems are found in only three parts of the world, the Yucatán Peninsula, Cuba and the Florida Peninsula, and are recognized as a wetland of international importance. The Los Petenes Biosphere Reserve is found within one of the regions of Mexico considered a priority under all existing categories: Regiones Prioritarias Terrestres (RPTs or Priority Terrestrial Regions) (Petenes-Ría Celestún, RPT No. 145); Regiones Marinas Prioritarias (RMPs or Priority Marine Regions) (Anillo de Cenotes, RMP No. 102.); and, Áreas de Importancia para la Conservación de las Aves (AICASs or Important Bird Conservation Areas) (Petenes, Clave SE-28). Considered the dominant vegetation, mangroves occupy approximately $50 \%$ of the terrestrial surface area of the Los Petenes Biosphere Reserve. Their principal components are the red mangrove (Rhizophora mangle), black mangrove (Avicennia germinans), white mangrove (Laguncularia racemosa) and the button mangrove (Conocarpus erectus). The mangroves of the Rio Verde study area (located at coordinates Latitude North: 20.756793 and Longitude East: 90.551896) are characterized as fringetype with riverine, fringe and scrub tendencies.

The municipality of Champotón is located in the central region of the state of Campeche. 
The Champotón river, located in Región Hidrológica Prioritaria (RHP or Priority Hydrological Region) No. $31\left(19^{\circ} 22^{\prime} \mathrm{LN}\right.$ and $\left.90^{\circ} 43^{\prime} \mathrm{LN}\right)$, is approximately 48 kilometers in length from its source close to the community of San Juan Carpizo to where it discharges into the Gulf of Mexico (Figure 1). The Champotón river basin is close to $650 \mathrm{~km}^{2}$ in area, while the river's volume reaches an annual average of approximately 483.93 million $\mathrm{m}^{3}$. Its median discharge has been estimated at $0.2 \times 10^{9} \mathrm{~m}^{3} \mathrm{year}^{-1}$, while its mouth is approximately $85 \mathrm{~m}$ wide with an median depth that varies from 2.5 to $4.5 \mathrm{~m}$ depending on the tides. The predominant climate is warm subtropical with rains in the summer, with a total annual precipitation of $1100-1500 \mathrm{~mm}$, while the average annual temperature is between 26 and $28^{\circ} \mathrm{C}$. The predominant soil types are mainly vertisol, gleysol and lithosol. The Comisión Nacional para el Conocimiento y Uso de la Biodiversidad (CONABIO or the Mexican National Commission for the Knowledge and Use of Biodiversity) identifies various types of vegetation in the Champotón river basin, such as tall semideciduous forests, medium subdeciduous forests, low floodable forests, low flood forest, mangroves, flood-prone palm groves, thorn scrub, savannah and cultivated grassland. Among the main anthropogenic activities undertaken in the Champotón river basin are agricultural practices and, to a lesser extent, livestock farming and tilapia aquaculture. Wastewater discharge from the La Joya S.A de C.V. sugar mill, based in the former ranch at Haltunchen, is carried by run-off into the river during the rainy season (Dzul-Caamal et al., 2016). The area of mangrove studied in the present research is found on the margin of the Champotón river, at the coordinates 19.35 Latitude and -90.7167 Longitude (Figure 1).

The Laguna de Términos Flora and Fauna Protection Area (Área de Protección de Flora y Fauna de Laguna de Términos or APFFLT) is located between $18^{\circ} 01^{\prime} 54^{\prime \prime}$ and $19^{\circ} 13^{\prime} 30^{\prime \prime}$ Latitude North and 92 $32^{\prime} 33^{\prime \prime}$ and 90 59'15" Longitude West. Aquatic and terrestrial plant associations are found in the APFFLT, with high biodiversity, wherein 374 plant species and 1,468 fauna species are identified, the majority of which have been traditionally exploited since pre-hispanic times by the local communities. The surrounding vegetation mainly comprises four mangrove species: $R$. mangle; A. germinans; L. racemose; and C. erectus.

The trees of the $R$. mangle forests in the Atasta, Río San Pedro, and Sontecomapan areas and the mouth of the Grijalva river reach a height of $30 \mathrm{~m}$. and above. In the northern part of the laguna, the A. germinans trees reach a height of up to $15 \mathrm{~m}$., while, in the internal areas of the Sabancuy estuary that border the edge of the laguna, scrub-type mangroves, dominated by $R$. mangle and with a height of no higher than $1.5 \mathrm{~m}$., can be found on an exposed soil on a karst topography (Agraz-Hernández et al., 2011 Figure 1).

\section{Chemistry of interstitial water}

Two PVC tubes, with a diameter of $10 \mathrm{~cm}$ and a length of $1.5 \mathrm{~m}$, were installed at each study site. Orifices, $1 \mathrm{~cm}$ in diameter, were made in the lower part of each tube up to the $30 \mathrm{~cm}$ mark (the depth at which the maximum root biomass is found). Each tube was installed at a depth of $50 \mathrm{~cm}$ from the surface of the soil. The sample was collected once the tube had been drained and the filtration of water into the interior of the tube had been stabilized. In order to determine the availability of the dissolved oxygen in the interstitial water (Chan-Keb et al., 2018), the redox potential was measured by means of the chemical activity of the electrons using a multi-parametric probe $(\mathrm{HACH}$, model HQ40d) and an ORP (Oxidation Redox Potential) electrode. The salinity was determined with an A\&O 
refractometer, with a 0 to 100 PSU (Practical Salinity Units) measurement interval (Agraz-Hernández et al., 2011). The interstitial water collected during the rainy season in each piezometer was then transferred, via a vacuum pump, to $50 \mathrm{ml}$ flasks, to enable sulfate concentration measurement, which was carried out based on the criteria proposed by Agraz-Hernández et al. (2018) using ion chromatography (IC advanced 861).

\section{Determination of the physicochemical parameters of the mangrove sediments}

The soil samples were extracted using corers constructed with PVC tubes $15.24 \mathrm{~cm}$ in diameter and $10 \mathrm{~cm}$ deep, following the criteria proposed by Satheeshkumar and Khan (2009). Two samples were taken from the first strip of mangrove forest. The $\mathrm{pH}$ and redox potential of the soil were taken in situ using a multiparametric IQ150. The samples were transported to the coastal wetlands laboratory for physicochemical analysis.

\section{Determination of carbon and nitrogen}

The organic carbon and total nitrogen (TN) analysis was conducted via the dry combustion method based on the Dumas principal described by Ruiz-Fernandez et al. (2018), using a FLASH 2000 elemental analyzer.

Between 5 and $10 \mathrm{mg}$ of soil was weighed in silver capsules using a METLER TOLEDO XP6 micro balance with a $0.001 \mathrm{mg}$ precision. The soil was then digested with $\mathrm{HCl}$ 1:1 until the inorganic carbon was eliminated, as indicated when the sample ceased bubbling, and then placed in the elemental analyzer. The samples were dried on a heating plate at $50^{\circ} \mathrm{C}$ and then sealed. In order to obtain precise results, the elemental analyzer was calibrated using both the known standard (sulfanilamide and methionine) and a target.

\section{Soil bulk density}

The Soil bulk density was determined via the known volume cylinder method $\left(\mathrm{gcm}^{-3}\right)$ (Rodríguez-Fuentes and Rodríguez-Absi, 2002). This method consists in introducing the cylinder (sampler) to a depth of $10 \mathrm{~cm}$ and a diameter of $15.2 \mathrm{~cm}$, with the cylinder, now saturated with soil, then extracted and transferred to a receptacle and placed in an oven at $105^{\circ} \mathrm{C}$ until the constant dry weight is obtained. The Soil bulk density was then measured by dividing the dry soil weight by the volume of the cylinder.

\section{Quantification of organic carbon sequestered in the soil}

The carbon content in each $10 \mathrm{~cm}$ soil core was obtained by multiplying the carbon concentration per depth interval by its apparent density, the corresponding length, and the average amount of organic carbon in the cores extracted per parcel, giving, as a result, the subterranean carbon for each physiognomic type of mangrove identified $\left(\mathrm{Mg} \mathrm{C} \mathrm{ha}^{-1}\right)$.

\section{Methane Emission}

Methane emissions were determined using static cylindrical chambers manufactured from polyvinyl chloride (PVC) tubes, caps and couplings, which were closed prior to high tide, allowing the accumulation of gases in a minimum time period of three hours, with another sample extracted during low tide. The extraction of gas was undertaken, using a vacuum pump, via brass connectors with $1 / 2$ " hoses and a 1-liter Tedlar Bag manufactured with classic duPont ${ }^{\circledR}$ film (SNC, cat No. 232 - 01). The bags were transported to the coastal wetland laboratory, to determine the methane $\left(\mathrm{CH}_{4}\right)$ level via a Trace 1310 gas 
chromatograph fitted with a flame ionization detector (FID) and a Q $15 \mathrm{~m} \mathrm{x} 0.32 \times$ $10.0 \mu \mathrm{m}$ TG-Bond column. The working temperatures were $225^{\circ} \mathrm{C}$ (FID), $230^{\circ} \mathrm{C}$ (SSL injector) and $60^{\circ} \mathrm{C}$. Nitrogen $\left(\mathrm{N}_{2}\right)$ at $40 \mathrm{~mL} / \mathrm{min}$ was used as a carrier gas, while the compressed air flow was $350 \mathrm{~mL} / \mathrm{min}$ and $\mathrm{H}_{2}$ was used as a catalyzer gas for the FID at $35 \mathrm{~mL} / \mathrm{min}$. The methane concentrations were calculated based on the criteria proposed by Mendoza-Mojica et al. (2013).

$$
\text { Flow }=\frac{(C f-C i) \times \text { Volume }}{\text { Time } x \text { Area }}
$$

where $\mathrm{Ci}$ is the initial concentration and $\mathrm{Cf}$ the final concentration of $\mathrm{CH}_{4}$ gas in $\mathrm{mg} \mathrm{L}^{-1}$, Volume $=$ Volume of the static chamber in liters,

Time $=$ Time in the emission of methane gas in hours,

Area $=$ Area of the static camera in $\mathrm{m}^{2}$,

Flow $=$ Flow of the emission of methane gas in $\mathrm{CH}_{4} \mathrm{~m}^{-2} \mathrm{~h}^{-1}$.

\section{Statistical analysis}

A database was generated with the physicochemical parameters of the sediment (NT, Soil bulk density, $\mathrm{pH}$, carbon sequestration and methane emission), as well as the chemical parameters of the interstitial water (salinity, redox potential and sulfates), in the mangrove forests of the coast of the state of Campeche.

A one-way analysis of variance was applied in order to determine the variation among the sites (mangrove areas). Subsequent post hoc analysis Fisher's Least Significant Difference test (LSD) was applied to determine significant differences among means at $\mathrm{p} \leq 0.05$ level of significance. For this analysis, the normality of the physicochemical variables was validated by means with a significance level of $\alpha=0.05$ on non-compliance with the supposed normal distribution. The data were transformed using the Box-Cox method as recommended in Zar (2010), while, principal component analysis (PCA) was applied in order to determine the environmental variables of greatest importance to the soil and interstitial water of the mangrove forests. A simple linear regression analysis was then performed in order establish the relationship among the physicochemical parameters of the interstitial water and sediment in terms of carbon sequestration, methane emission and total nitrogen concentration. The statistical analysis was undertaken with a significance level of $\alpha=0.05$, using the Statgraphics Centurion XVII software (Statpoint, 2014).

\section{Results}

\section{Physicochemical parameters of the interstitial water}

In the rainy season, mesohaline conditions presented in the three mangrove areas under study (RBP, RC and LT), which comprise the large part of the cover found in the state of Campeche. The highest salinity levels were registered in RBP and LT $(36.0 \pm 8.7$ and $33.5 \pm 8.3$ UPS), while the lowest levels were observed in RC $(26.3 \pm 8.3$ UPS $)$. On applying a one-way ANOVA, significant differences were established in the salinity levels measured in three study areas $\left(\mathrm{F}_{2,29}=3.8, \mathrm{p}=0.033\right)$ (Figure 3a). Similar behavior was registered for sulfate concentration, with maximum levels found in RBP and LT $\left(2976.2 \pm 1255.2 \mathrm{mg} \mathrm{L}^{-1}\right.$ and $\left.3,180 \pm 1580 \mathrm{mg} \mathrm{L}^{-1}\right)$ and minimum levels in $\mathrm{RC}$ 
$\left(2,333 \pm 1,074 \mathrm{mg} \mathrm{L}^{-1}\right)$; however, significant differences were not found $\left(\mathrm{F}_{2,29}=0.99\right.$, $\mathrm{p}=0.38)($ Figure $3 b)$.

The oxido-reduction conditions established in the interstitial water in RBP were an oxic-hypoxic type of $-290 \pm 23 \mathrm{mV}$, while RC and LT presented hypoxic-type conditions, with values of $-321 \pm 27$ and $-301 \pm 47 \mathrm{mV}$, respectively. Significant differences were not established during the rainy reason along the length of the Campeche coast $\left(\mathrm{F}_{2,29}=1.28, \mathrm{p}=0.29\right)$ (Figure 3c).

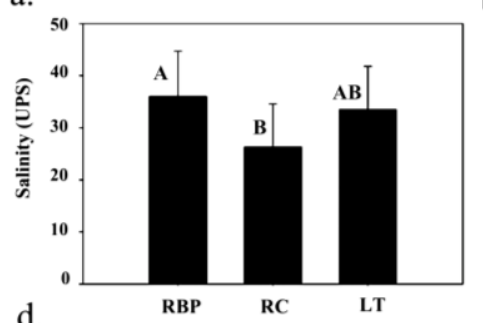

d.

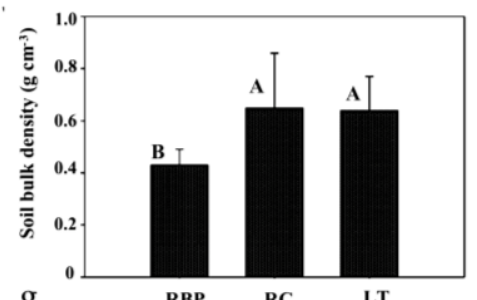

g.

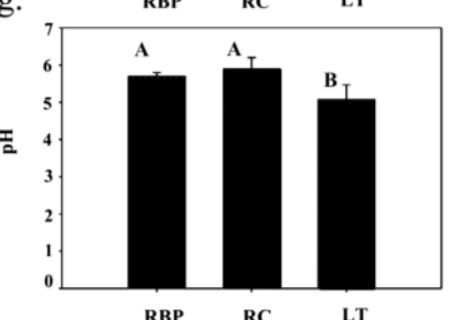

b.
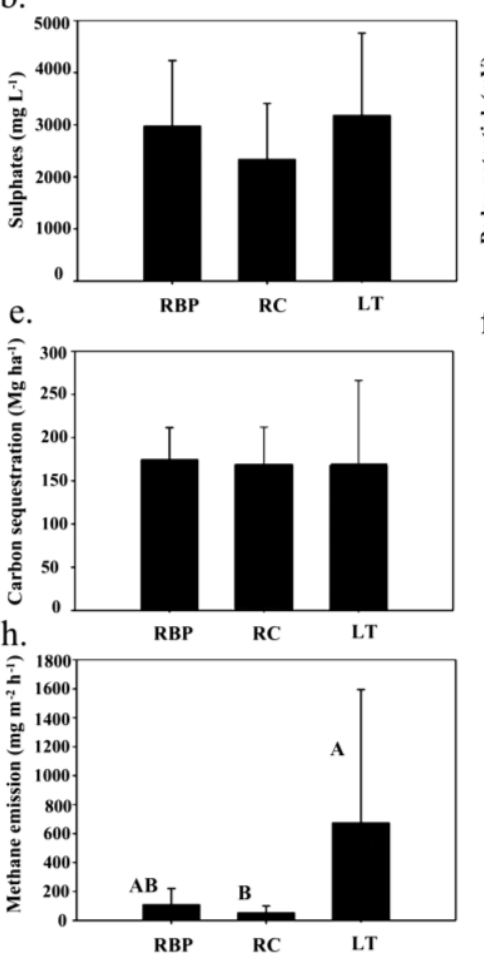

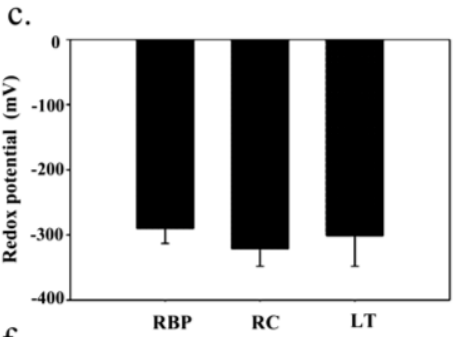

f.

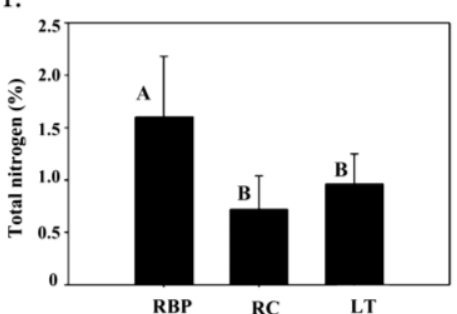

Figure 3. Physicochemical parameters of the interstitial water and soil in three mangrove ecosystems on the coast of the Campeche state. RBP: Reserva de la Biosfera de los Petenes (Los

Petenes Biosphere Reserve); RC: Río Champotón (Champotón river); and, LT: Laguna de Términos. the site that do not share a letter are significantly different $(p \leq 0.05)$. Error bars represent standard deviation

\section{Physicochemical parameters of the soil}

The highest Soil bulk density values were registered in RC and LT $\left(0.65 \pm 0.21 \mathrm{gcm}^{-3}\right.$ and $\left.0.64 \pm 0.13 \mathrm{~g} \mathrm{~cm}^{-3}\right)$, while they were lower in $\operatorname{RBP}\left(0.43 \pm 0.06 \mathrm{~g} \mathrm{~cm}^{-3}\right)$, presenting significant differences $\left(\mathrm{F}_{2,29}=6.4, \mathrm{p}=0.005\right)$ (Figure $3 d$ ).

The highest concentration of total nitrogen (NT) in the soil was $1.6 \pm 0.58 \%$ in RBP, followed by $0.96 \pm 0.29 \%$ for LT and, finally, $0.72 \pm 0.32 \%$ in RC, with significant differences found among them $\left(\mathrm{F}_{2,29}=12.83, \mathrm{p}=0.0001\right)$ (Figure $\left.3 f\right)$.

The $\mathrm{pH}$ conditions of the soil were acidic in the three mangrove areas studied: $\mathrm{RC}$ $(5.9 \pm 0.3)$; RBP $(5.7 \pm 0.1)$; and, LT $(5.07 \pm 0.40)$. The one-way ANOVA test revealed significant differences among these ecosystems, despite the minimal differences $\left(\mathrm{F}_{2,29}=\right.$ 20.29, $\mathrm{p}=0.0001)$ (Figure 3g). 


\section{Carbon sequestration}

The highest carbon sequestration levels were observed in RBP $\left(174.6 \pm 37 \mathrm{Mg} \mathrm{ha}^{-1}\right)$, followed by RC and LT (169 $\pm 43 \mathrm{Mg} \mathrm{ha}^{-1}$ and $168 \pm 98 \mathrm{Mg} \mathrm{ha}^{-1}$, respectively), despite which, significant differences were not observed among the mangrove ecosystems in $\mathrm{RBP}, \mathrm{RC}$ and $\mathrm{LT}\left(\mathrm{F}_{2,29}=0.02, \mathrm{p}=0.97\right)$ (Figure 3e).

\section{Behavior of methane emissions}

Average methane emissions were higher in LT, with a flow of $673.24 \pm 922 \mathrm{mg} \mathrm{m}^{2} \mathrm{~h}^{-1}$, and lower in RBP and RC, with values of $109.80 \pm 111 \mathrm{mg} \mathrm{m}^{2} \mathrm{~h}^{-1}$ and $51.73 \pm$ $48 \mathrm{mg} \mathrm{m}^{2} \mathrm{~h}^{-1}$, respectively. These flows presented significant differences between the study areas $\left(\mathrm{F}_{2,29}=3.55, \mathrm{p}=0.042\right)$ (Figure $\left.3 h\right)$.

\section{Behavior of methane emissions, in terms of interstitial water conditions and the soil}

The results of the PCA, considering the variables of methane emissions and the physicochemistry of the interstitial water and soil, presented three components that explain $71.01 \%$ of the total variance in the mangrove forests that border the coast of the state of Campeche. Thus, the first component (28.72\%) describes the most important sulfates with a direct relationship with both the salinity and the redox potential of the interstitial water. The second component $(22.02 \%)$ defines the $\mathrm{pH}$ of the soil as the most important factor, presenting an inverse correlation with the methane emissions, while the third component $(20.27 \%)$ shows that carbon sequestration is the most important parameter, establishing a direct relationship with the TN (Table 1).

Table 1. PCA applied to chemical parameters in the soils of the mangrove forests, with an accumulated $71.01 \%$ of the total variance in the first three factors of the mangrove forests on the coast of the state of Campeche

\begin{tabular}{c|c|c|c}
\hline Parameter & $\begin{array}{c}\text { Component I } \\
(\mathbf{2 8 . 7 2 \%})\end{array}$ & $\begin{array}{c}\text { Component II } \\
\mathbf{( 2 2 . 0 2 \% )}\end{array}$ & $\begin{array}{c}\text { Component III } \\
(\mathbf{2 0 . 2 7 \% )}\end{array}$ \\
\hline $\mathrm{ECH}_{4}\left(\mathrm{mg} \mathrm{m}^{-2} \mathrm{~h}^{-1}\right)$ & -0.026 & $\mathbf{0 . 6 5 0}$ & 0.197 \\
Soil bulk density $\left(\mathrm{g} \mathrm{cm}^{-3}\right)$ & 0.337 & 0.242 & -0.315 \\
$\mathrm{CS}\left(\mathrm{Mg} \mathrm{ha}^{-1}\right)$ & -0.137 & 0.075 & $\mathbf{- 0 . 7 3 5}$ \\
$\mathrm{TN}(\%) \mathrm{S}$ & -0.268 & -0.139 & $\mathbf{- 0 . 4 7 4}$ \\
pH S & -0.126 & $\mathbf{- 0 . 6 7 1}$ & 0.146 \\
Redox potential (mV) IW & $\mathbf{0 . 4 5 0}$ & -0.160 & -0.199 \\
Salinity (UPS) IW & $\mathbf{0 . 5 1 3}$ & -0.098 & -0.147 \\
$\mathrm{SO}_{4}^{-2}$ (mg L-1) IW & $\mathbf{0 . 5 6 0}$ & -0.097 & 0.120 \\
\hline
\end{tabular}

CS: Carbon sequestration; TN: Total nitrogen; $\mathrm{ECH}_{4}$ : Methane emission; $\mathrm{SO}_{4}{ }^{-2}$ : sulfates; IW: Interstitial water; and, S: soil

\section{Modeling of carbon sequestration and methane emissions, in relation to the chemical conditions of the interstitial water and soil}

In general, the mangrove forests that border the northern (RBP), central (RC) and southern (LT) regions of the state of Campeche have established a direct relationship between carbon sequestration and the TN concentration in the soil (Table 2). The TN presented a direct relationship with carbon sequestration, while methane emissions registered an inverse relationship with the $\mathrm{pH}$ of the soil (Table 2). 
Table 2. Simple linear regression analysis of carbon sequestration, total nitrogen and methane emissions using the physicochemical parameters of the mangrove forests on the edge of the three mangrove ecosystems found on the coast of the state of Campeche

\begin{tabular}{|c|c|c|c|}
\hline $\begin{array}{c}\text { Ecosystem/dependent } \\
\text { variable (Y) }\end{array}$ & Equation & $\mathbf{R}^{2}$ & $\mathbf{p}$ \\
\hline \multicolumn{4}{|c|}{ Los Petenes Biosphere Reserve (RBP) } \\
\hline $\mathrm{ECH}_{4}\left(\mathrm{mg} \mathrm{m}^{-2} \mathrm{~h}^{-1}\right)$ & $Y=-1064-4.091 \mathrm{X}_{2}$ & 0.84 & 0.004 \\
\hline $\mathrm{ECH}_{4}\left(\mathrm{mg} \mathrm{m}^{-2} \mathrm{~h}^{-1}\right)$ & $\mathrm{Y}=482.4-2.245 \mathrm{X}_{6}$ & 0.67 & 0.025 \\
\hline $\mathrm{CS}\left(\mathrm{Mg} \mathrm{ha}^{-1}\right)$ & $\mathrm{Y}=79.99+59.56 \mathrm{X}_{7}$ & 0.76 & 0.01 \\
\hline \multicolumn{4}{|c|}{ Champotón river } \\
\hline $\mathrm{SC}\left(\mathrm{Mg} \mathrm{ha}^{-1}\right)$ & $\mathrm{Y}=-116.3+11.53 \mathrm{X}_{1}$ & 0.79 & 0.008 \\
\hline $\mathrm{CS}\left(\mathrm{Mg} \mathrm{ha}^{-1}\right)$ & $Y=-23.34+264.4 X_{7}$ & 0.77 & 0.004 \\
\hline \multicolumn{4}{|c|}{ Laguna de Términos (LT) } \\
\hline $\mathrm{SO}_{4}^{-2}\left(\mathrm{mg} \mathrm{L}^{-1}\right)$ & $Y=-1946+155.1 X_{1}$ & 0.92 & 0.0001 \\
\hline $\mathrm{TN}_{\text {suelo }}(\%)$ & $Y=-0.1744+0.0067 X_{6}$ & 0.67 & 0.001 \\
\hline $\mathrm{ECH}_{4}\left(\mathrm{mg} \mathrm{m}^{-2} \mathrm{~h}^{-1}\right)$ & $\mathrm{Y}=12027-2190 \mathrm{X}_{5}$ & 0.77 & 0.0001 \\
\hline $\mathrm{SO}_{4}^{-2}\left(\mathrm{mg} \mathrm{L}^{-1}\right)$ & $\mathrm{Y}=9285+21.55 \mathrm{X}_{2}$ & 0.69 & 0.001 \\
\hline
\end{tabular}

CS: Carbon Sequestration; TN: Total nitrogen; $\mathrm{ECH}_{4}$ : Methane emissions; $\mathrm{SO}_{4}^{-2}$ : sulfates.

Where: $\mathrm{X}_{1}$ (Salinity in UPS); $\mathrm{X}_{2}$ (IW redox potential in $\mathrm{mV}$ ); $\mathrm{X}_{3}$ (Sulfates in $\mathrm{mg} \mathrm{L}^{-1}$ ); $\mathrm{X}_{4}$ (Soil bulk density in $\left.\mathrm{g} \mathrm{cm}^{-3}\right) ; \mathrm{X}_{5}(\mathrm{pH}) ; \mathrm{X}_{6}\left(\mathrm{CS}\right.$ in $\left.\mathrm{Mg} \mathrm{ha}^{-1}\right)$; and, $\mathrm{X}_{7}(\mathrm{TN}$ in \%). Level of significance: $\alpha=0.05$

Specifically, methane emissions in RBP presented an inverse relationship in terms of the redox potential of the interstitial water and carbon sequestration, while the contrary was found for the RC wetlands, in which carbon sequestration presented a direct relationship with the salinity of the interstitial water and the concentration of TN in the soil. For LT, a direct correlation was found with the sulfate concentration, salinity and redox potential of the interstitial water. Similarly, the relationships were significant $(\mathrm{p}<0.05)$ (Table 2).

\section{Discussion}

\section{Behavior of the physicochemical parameters of the interstitial water}

The salinity and sulfate concentration varied among sites, increasing from south (LT) to north (RBP). This may be related to the level of ingress of seawater and the ingress from superficial and subterranean rivers, causing a dilution effect in the interstitial water (Chan-Keb et al., 2018) in each of the areas. The ingress of freshwater into the mangroves in this lagoon system is drawn from the Champotón river to the center, with a higher flow in the south (LT), from such sources as the San Pedro, San Pablo, Grijalva and Palizada rivers (Chan-Keb et al., 2018), and descreasing towards the north. The results of this study are similar to that reported by Barreto et al. (2016), who describe how sulfates originate in the seawater and are directly related to the salinity of the interstitial water. Moreover, in Zanzíbar, Africa (Sitoe et al., 2014), and in Florida, USA (Rivera-Monroy et al., 2007), the low salinity levels found in the mangroves are reported to indicate a higher level of freshwater ingress. Flores-Verdugo et al. (2007) establish that, in the mangrove forests, the interstitial salinity levels are caused by the hydrological pattern, variation in the level of the soil, the evaporation rate and, moreover, the ingress of salts of anthropic origin. The general tendency of the oxido-reduction conditions of the interstitial water in the mangrove areas (RBP, RC and LT) results from the different levels of ingress of freshwater (rivers) and seawater (tides). It is also a consequence of the intensity and 
direction of the winds by season of the year ('northerlies' and 'southerlies') and, therefore, the circulation of the lagoon system and/or the marine front.

In turn, this tendency is defined by annual hydrometeorological cycles (precipitation) and the type of anthropic pressure exerted on each ecosystem. Gleason et al. (2003) state that the oxido-reduction conditions are related to hydrology (the residence time of the water, the frequency of flooding due to the effect of the tides, and the ingress of urban and/or industrial wastewater). The highest redox potential values were registered in RBP due to the lower water residence time caused by the continual ebb and flow of the tide, as well as the higher level of freshwater ingress (interstitial and subterranean) during the rainy season. In this regard, Chen et al. (2010) indicate that, during the rainy season, the redox potential increases, as a result of the runoff caused by the rain, the increased river flow and the effect of the tide.

The RC and LT study areas, despite receiving a higher level of freshwater ingress from the rivers than that received by the wetlands of $\mathrm{RBP}$, receive large amounts of organic material resulting from anthropogenic activities, thus causing a greater demand for dissolved oxygen, due to the oxidation of organic material, and, thus, a decrease in redox potential. Mitsch and Gosselink (2000) describe how the hydrological pattern (hydroperiod) and the ingress of organic material are determinants of the oxido-reduction conditions in the mangrove forests, establishing changes in the redox potential. Similar redox potential values have been reported in both Campeche (Chan-Keb et al., 2018) and the Laguna de Términos Flora and Fauna Protection Area (Agraz-Hernandez et al., 2012).

\section{Behavior of the physicochemical parameters of the soil}

The variations found in Soil bulk density in the study areas are attributed to the variations in the organic and inorganic composition of the soil among these ecosystems (Agraz-Hernández et al., 2011). Specifically, RBP presents a lower apparent density, due to the high organic material content, the opposite of which was found in RC and LT. Similar behavior is described by Chen and Twilley (2005) in the soils of the mangroves of the state of Florida, USA, and by Moreno et al. (2002) in soils of the mangroves of the state of Tabasco, Mexico.

The general behavior of the $\mathrm{pH}$ registered in the three study areas (RBP, RC and LT) presented acidic conditions due to the production of hydrogen sulphide and the formation of humic and fulvic acids during the decomposition of the organic material caused by the ingress of sulfates originating in seawater. Moreover, this was also due to the discharge of wastewater from agricultural and livestock activities. This behavior is similar to that reported by Marchand et al. (2004) and Moreno et al. (2002).

\section{Carbon sequestration}

In general, similar carbon sequestration was found among the RBP, RC and LT study areas $(\mathrm{p}>0.05)$, despite presenting differences in the physicochemical parameters of the interstitial water and the soil. The foregoing is attributed to the interaction among the hydroperiod, topography and ingress of organic material (Kristensen et al., 2008; Schmidt et al., 2011; Alongi, 2014; Lehmann and Kleber, 2015). The higher levels of carbon sequestration registered in the RBP and RC study areas may be attributed to the ingress of organic material resulting from the generation of $R$. mangle litterfall. $R$. mangle leaves contain a high concentration of lignin, cellulose and lipids, which are complex in structure, thus causing a slow decomposition speed and favoring carbon sequestration (Hogarth, 1999). Other influential factors are the mineralization of organic material and 
the decrease in microbial activity in response to the high salinity concentrations (Kreuzwieser et al., 2003; Chen et al., 2010). The opposite was found in LT, where carbon sequestration was lower due to the greater dominance of $A$. germinans (Chan-Keb et al., 2018).

The lower water residence time in RC and LT has established hypoxic conditions in the interstitial water, thus limiting the degradation of organic material and generating carbon sequestration. However, the carbon sequestration results identified by this research are lower than those reported by Kauffman et al. $(2011,2013)$ in the mangroves of Micronesia (53.4 Mg ha' $\mathrm{Mg}^{-1}$, Bangladesh (16.9 $\mathrm{Mg} \mathrm{ha}^{-1}$ ) and Indonesia (28 $\left.\mathrm{Mg} \mathrm{ha}^{-1}\right)$, at a depth of $10 \mathrm{~cm}$.

\section{Concentration of total nitrogen}

The NT concentration in the three study areas (RBP, RC and LT) presented significant differences $(p<0.05)$, due to the ingress of organic material originating in both litterfall and anthropogenic activity (Rivera-Monroy et al., 1995, 2007). Similarly, the TN concentration in RC and LT may be attributed to the discharge of urban, agricultural and livestock wastewater. Adame et al. (2015) and Alongi et al. (2004) describe how the levels of carbon and nitrogen in the mangroves also originate in allochtonous sources, such as the discharge of urban, agricultural and livestock wastewater, as observed in this study.

Carbon sequestration presented a direct and significant relationship $(\mathrm{p}<0.05)$ with the concentration of total nitrogen in the three study areas (RBP, RC and LT) (Tables 1 and 2).

In this regard, authors such as Yimer et al. (2006) and Xue and Shaoshan (2019) mention that mangrove forests are efficient in the accumulation of not only carbon, but also nitrogen (Vázquez-Lule et al., 2019).

This is due to the interaction that occurs during the biogeochemical cycle, with these authors emphasizing that nitrogen concentration increases along with increases in carbon sequestration.

\section{Behavior of methane emissions}

The variation in methane emissions $(\mathrm{p}<0.05)$ in the three mangrove ecosystems on the coast of the state of Campeche results from the differences in the dynamics of the carbon present in first $10 \mathrm{~cm}$ of soil, influenced by the prevailing environmental conditions in each study area (Agraz-Hernández et al., 2015). According to the results obtained by the present study, the highest methane emissions are released in the mangrove forest of the LT study area.

The foregoing is a consequence of the constant ingress of terrigenous nutrients (from the Atasta and Palizada rivers), anthropogenic activity, topographic gradient, and, thus, the water residence time and the extent of the flooding, reducing oxido-reduction conditions, $\mathrm{pH}$ levels, and salinity, in contrast with the forests of RC and RBP.

Studies by various authors show that increased organic discharge into coastal ecosystems result in significant increases in methane gas emissions (Heyer and Berger, 2000; Purvaja and Ramesh, 2001; Muñoz-Hincapie et al., 2002; Chiu et al., 2004; Punshon and Moore, 2004), caused by the bacterial degradation of this organic material during the processes of methanogenesis. Authors such as Purvaja and Ramesh (2001) consider that mangrove soils are sources of the emission of $\mathrm{CH}_{4}$, given that they are especially sensitive to methanogenesis and other biogeochemical processes. This increases considerably due to other factors, such as changes to the hydrological pattern, 
the ingress of wastewater, or deforestation. However, the results of the present research indicate lower levels than those reported by Alongi et al. (2005), who report an emission level of $0.088 \mathrm{mg} \mathrm{m}^{-2} \mathrm{~h}^{-1}$ in the Changning Estuary in China. Moreover, the results obtained by the present study are similar to that reported by Purvaja and Ramesh (2001), who reported emission levels of $15.41 \mathrm{mg} \mathrm{m}^{-2} \mathrm{~h}^{-1}$ for the Adyar Estuary in India, while May-Herrera (2017) report methane emissions ranging from 45 to $948 \mathrm{mg} \mathrm{m}^{-2} \mathrm{~h}^{-1}$ in the San Pedro river, in the state of Nayarit, Mexico.

Mukhopadhyay et al. (2002) report emissions of 15.4 to $32 \mathrm{mg} \mathrm{m}^{-2} \mathrm{~h}^{-1}$ in mangrove forests recieving runoff from the Sundarban river in India.

\section{Conclusions}

The highest amount of sequestered carbon was registered in the Los Petenes Biosphere Reserve, while, in comparison, significant differences were not observed for the Champotón river and Laguna de Términos. In turn, the carbon sequestration presented a direct relationship with the concentration of total nitrogen in the three study areas. This may be due to the production of litterfall by the dominant species, with $R$. mangle dominating the northern and central areas of the Campeche coast, as well as the ingress of organic material and nitrogen of anthropogenic origin.

The highest methane emissions were registered in Laguna de Términos (673.24 \pm $\left.922 \mathrm{mg} \mathrm{m}^{-2} \mathrm{~h}^{-1}\right)$, while the lowest were found in Champotón $\left(51.73 \pm 48 \mathrm{mg} \mathrm{m}^{-2} \mathrm{~h}^{-1}\right)$, with significant differences found between the study areas $(\mathrm{p}<0.05)$. The highest level of methane released in the mangrove forest in LT presented an inverse relationship with the $\mathrm{pH}$ of the soil.

This is a consequence of the constant ingress of terrigenous nutrients (from the Atasta and Palizada rivers), anthropogenic activity, topographic gradient, and, thus, the water residence time and the extent of the flooding, reducing oxido-reduction conditions, $\mathrm{pH}$ levels, and salinity, in contrast with the forests of RC and RBP.

The results of the present study demonstrate that the quantity of carbon and methane emitted on the coast of the state of Campeche depended on the hydrochemical variables of both the soil and the interstitial water, as well as the different prevailing anthropic pressures in each ecosystem.

The results in this study were obtained only in the rainy season, so carbon sequestration and methane emission could be different throughout year and to be influenced by other physicochemical parameters of interstitial water and soil. For further research on this topic it is necessary to include physicochemical parameters of interstitial water such as micronutrients and monitor the profiles (quantities) of sequestration and emission of methane at three different times of the year.

\section{REFERENCES}

[1] Abril, G., Iversen, N. (2002): Methane dynamics in a Shallow, non-didal estuary (Ramders Fjord, Denmarks). - Marine Ecolology Progress Series 230: 171-181.

[2] Adame, M. F., Kauffman, J. B., Medina, I., Gamboa, J. N., Torres, O., Caamal, J. P., Reza, M., Herrera-Silveira, J. A. (2013): Carbon stocks of tropical coastal wetlands within the karstic landscape of the Mexican Caribbean. - PloS One 8(2): e56569. 
[3] Adame, M. F., Santini, N. S., Tovilla, C., Vázquez-Lule, A., Castro, L., Guevara, M. (2015): Carbon stocks and soil sequestration rates of tropical riverine wetlands. Biogeosciences 12(12): 3805-3818.

[4] Agraz-Hernández, C. M., García Zaragoza, C., Iriarte-Vivar, S., Flores-Verdugo, F. J., Moreno Casasola, P. (2011): Forest structure, productivity and species phenology of mangroves in the La Mancha lagoon in the Atlantic coast of Mexico. - Wetlands Ecology Management 19: 273-293.

[5] Agraz-Hernández, C. M., Chan-Keb, C. A., Iriarte-Vivar, S., Posada-Vanegas, G., VegaSerratos, B. E., Osti-Sáenz, J. (2015): Phenological variation of Rhizophora mangle L. and ground water chemistry associated to changes of the precipitation. - Hydrobiológica 25(1): 61-73.

[6] Agraz-Hernández, C. M., del Río-Rodríguez, R., Chan-Keb, C. A., Osti-Saenz, J., MuñizSalazar, R. (2018): Nutrient Removal Efficiency of Rhizophora mangle (L.) Seedlings Exposed to Experimental Dumping of Municipal Waters. - Diversity 10(1): 1-16.

[7] Alongi, D. M., Sasekumar, A., Chong, V. C. (2004): Sediment accumulation and organic material flux in a managed mangrove ecosystem: estimates of land-ocean- atmosphere exchange in peninsular Malaysia. - Mar. Geol. 208: 383-402.

[8] Alongi, D. M., Pfitzner, J., Trott, L. A., Tirendi, F., Dixon, P., Klumpp, D. W. (2005): Rapid sediment accumulation and microbial mineralization in forests of the mangrove Kandelia candel in the Jiulongjiang Estuary, China. - Estuar. Coast. Shelf Sci. 63(4): 605618.

[9] Alongi, D. M. (2014): Carbon cycling and storage in mangrove forests. - Annual review of marine science 6: 195-219.

[10] Barreto, M. B., Mónaco, S. L., Díaz, R., Barreto-Pittol, E., Lopez, L., Ruaro Peralba, M. do C. (2016): Soil organic carbon of mangrove forest (Rhizophora and Avicennia) of the Venezuelan Caribbean coast. - Organic Geochemistry 100: 51-61.

[11] Chan-Keb, C. A., Agraz-Hernández, C. M., Muñiz-Salazar, R., Posada-Vanegas, G., OstiSáenz, J., Reyes Castellano, J. E., Conde-Medina, K. P., Vega-Serratos, B. E. (2018): Ecophysiological Response of Rhizophora mangle to the Variation in Hydrochemistry during Five Years along the Coast of Campeche, México. - Diversity 10(1): 1-9.

[12] Chen, R., Twilley, R. (2005): A simulation model of organic matter and nutrient accumulation in mangrove wetland soils. - Biogeochemistry 44(1): 93-118.

[13] Chen, G. C., Tam, N. F. Y., Ye, Y. (2010): Summer fluxes of atmospheric greenhouse gases $\mathrm{N}_{2} \mathrm{O}, \mathrm{CH}_{4}$ and $\mathrm{CO}_{2}$ from mangrove soil in South China. - Sci Total Environ 408: 2761-2767.

[14] Chiu, C. Y., Lee, S. C., Chen, T. H., Tian, G. (2004): Denitrification associated N loss in mangrove soil. - Nutrient Cycling in Agroecosystems 69: 185-189.

[15] CONABIO (2009): Manglares de México: Extensión y distribución. - Comisión Nacional para el Conocimiento y Uso de la Biodiversidad. Mexico D.F.

[16] De la Peña, A., Rojas, C. A., De la Peña, M. (2010): Valoración económica del manglar por el almacenamiento de carbono, Ciénaga Grande de Santa Marta. - Clío América 4(7): 133-150.

[17] Dzul-Caamal, R., Hernández-López, A., Gonzalez-Jáuregui, M., Padilla, S. E., GirónPérez, M. I., Vega-López, A. (2016): Usefulness of oxidative stress biomarkers evaluated in the snout scraping, serum and Peripheral Blood Cells of Crocodylus moreletii from Southeast Campeche for assessment of the toxic impact of PAHs, metals and total phenols. - Comparative Biochemistry and Physiology, Part A. 200: 35-46.

[18] Flores-Verdugo, F., Casasola, P. M., Agraz-Hernàndez, C. M., Rosas, H. L., Pardo, D. B., Bello, A. C. T. (2007): La topografía y el hidroperiodo: dos factores que condicionan la restauración de los humedales costeros. - Boletín de la Sociedad Botánica de México 80: $33-47$. 
[19] Giri, C., Ochieng, E., Tieszen, L. L., Zhu, Z., Singh, A., Loveland, T., Masek, J., Duke, N. (2011): Status and distribution of mangrove forests of the world using earth observation satellite data. - Global Ecology and Biogeography 20(1): 154-159.

[20] Gleason, S. M., Ewel, K. C., Hue, N. (2003): Soil redox conditions and plant-soil relationships in a Micronesian mangrove forest. - Estuarine, Coastal \& Shelf Science 56: 1065-1074.

[21] Graham, S. A., Craft, C. B., McCornick, P. V., Aldous, A. (2005): Forms and accumulation of soil P in natural and recently restored peatlands-upper Klamath Lake, Oregon, USA. Wetlands 25: 594-606.

[22] Heyer, J., Berger, U. (2000): Methane emission from the coastal area in the Southern Baltic Sea. - Estuarine, Costal and Shelf Science 51: 13-30.

[23] Hogarth, P. J. (1999): The biology of mangroves. Biology of habitats. - Oxford University Press, $228 \mathrm{p}$.

[24] Hooker, T. D., Compton, J. E. (2003): Forest ecosystem carbon and nitrogen accumulation during the first century after agricultural abandonment. - Ecol. Appl. 13: 299-313.

[25] IPCC. (2001): Atmospheric chemistry and greenhouse gases. - In: Houghton, J. H., Ding, Y., Griggs, D. J., Noguer, M., van der Linden, P. J., Dai, X., Maskell, K., Johnson, C. A. (eds.) Climate change 2001: The scientific basis. pp 239-287. Cambridge University Press, Nueva York.

[26] Kauffman, J. B., Heider, C., Cole, T. G., Dwire, K. A., Donato, D. C. (2011): Ecosystem carbon stocks of Micronesian mangrove forests. - Wetlands 31: 343-352.

[27] Kauffman, J. B., Donato, D. C., Adame, M. F. (2013): Protocolo para la medición, monitoreo y reporte de la estructura, biomasa y reservas de carbono de los manglares. Documento de Trabajo 117. Bogor, Indonesia: CIFOR.

[28] Kreuzwieser, J., Buchholtz, J., Rennerberg, H. (2003): Emission of methane and nitrous oxide by Australian mangrove ecosystems. - Plant Biol 5: 423-43.

[29] Kristensen, E., Bouillon, S., Dittmar, T., Marchand, C. (2008): Organic carbon dynamics in mangrove ecosystems: A review. - Aquat. Bot. 89: 201-219.

[30] Lal, R. (2005): Soil carbon sequestration in natural and managed tropical forest ecosystems. - J Sustain For 21: 1-30.

[31] Lehmann, J., Kleber, M. (2015): The contentious nature of soil organic matter. - Nature 528: 60-68.

[32] Liao, C., Luo, Y., Jiang, L., Zhou, X., Fang, C., Chen, J., Li, B. (2007): Invasion of Spartina alternifolia enhanced ecosystem carbon and nitrogen stocks in the Yangtze Estuary, China. - Ecosystems 10: 1351-1361.

[33] Marchand, C., Baltzer, F., Lallier-Vergès, E., Albéric, P. (2004): Pore water chemistry in mangrove sediments in relationship to species composition and developmental stage (French Guiana). - Marine Geology 208: 361-381.

[34] May-Herrera, C. I. (2017): Respuesta morfofisiológica del manglar ante el cambio de las condiciones ambientales y emisiones de metano por influencia antrópica. - Tesis de maestría Instituto EPOMEX Universidad Autónoma de Campeche. Campeche, Mexico.

[35] Mazda, Y., Magi, M., Kogo, M., Hong, P. N. (1997): Mangroves as a coastal protection from waves in the Tong King delta, Vietnam. - Mangr. and Salt Marsh. 1(2): 127-135.

[36] Mendoza Mojica, M., Martínez Arroyo, A., Espinosa Fuentes, M. de la L., Peralta Rosales, Ó., Castro Romero, T. (2013): Caracterización de dos lagunas costeras del Pacífico tropical mexicano en relación con el contenido de carbono y la captura y emisión de CH4 Y CO2. - Revista internacional de contaminación ambiental 29(2): 145-154.

[37] Mitsch, W. J., Gosselink, J. G. (2000): Wetlands. - 3rd edition, New York. John Wiley \& Sons, $920 \mathrm{p}$.

[38] Moreno-Cáliz, E., Guerrero-Peña, A., Gutiérrez- Castorena, M. C., Ortíz Solorio, C., Palma-López, D. J. (2002): Los manglares de Tabasco, una reserva natural de carbono. Maderas y bosques 8: 115-128. 
[39] Mukhopadhyay, S. K., Biswas, H., De, T. K., Sen, B. K., Sen, S., Jana, T. K. (2002): Impact of Sundarban mangrove biosphere on the carbon dioxide and methane mixing ratios at the NE Coast of Bay of Bengal, India. - Atmospheric Environment 36(4): 629-638.

[40] Muñoz-Hincapié, M., Morell, J. M., Corredor, J. E. (2002): Increase of nitrous oxide flux to the atmosphere upon nitrogen addition to red mangroves sediments. - Marine Pollution Bulletin 44: 992-996.

[41] Punshon, S., Moore, R. (2004): Nitrous oxide production and consumption in a eutrophic coastal embayment. - Marine Chemistry 91(1-4): 37-51.

[42] Purvaja, R., Ramesh, R. (2001): Natural and anthropogenic methane emission from coastal wetlands of South India. - Environ. Manage. 27(4): 547-557.

[43] Rivera-Monroy, V. H., de Mutsert, K., Twilley, R. R., Castaneda-Moya, E., Romigh, M. M., Davis, S. E. (2007): Patterns of nutrient exchange in a riverine mangrove forest in the Shark River estuary, Florida, USA. - Hydrobiologica 17(2): 169-178.

[44] Rodríguez-Fuentes, H., Rodríguez-Absi, J. (2000): Métodos de análisis de suelos y plantas: criterios de interpretación. - 1st ed., México D.F, Trillas, UANL.

[45] Rodríguez-Zúñiga, M. T., Troche-Souza, C., Vázquez-Lule, A. D., Márquez-Mendoza, J. D., Vázquez-Balderas, B., Valderrama-Landeros, L., Velázquez-Salazar, S., Cruz-López, M. I., Ressl, R., Uribe-Martínez, A., Cerdeira-Estrada, S. (2013): Manglares de México/Extensión, distribución y monitoreo. - Comisión Nacional para el Conocimiento y Uso de la biodiversidad. México D.F.

[46] Ruiz-Fernández, A. C., Agraz-Hernández, C. M., Sanchez-Cabeza, J. A., Díaz-Asencio, M., Pérez-Bernal, L. H., Keb, C. C., López-Mendoza, P. G., Correa, J. B., OntiverosCuadras, J. F., Saenz, J. O., Castellanos, J. R. (2018): Sediment geochemistry, accumulation rates and forest structure in a large tropical mangrove ecosystem. - Wetlands 38(2): 307-325.

[47] Sandoval-Castro, E., Dodd, R. S., Riosmena-Rodríguez, R., Enríquez-Paredes, L. M., Tovilla-Hernández, C., López-Vivas, J. M., Muñiz-Salazar, R. (2014): Post-glacial expansion and population genetic divergence of mangrove species Avicennia germinans (L.) Stearn and Rhizophora mangle L. along the Mexican coast. - PLoS One 9(4): e93358.

[48] Satheeshkumar, P., Khan, B. A. (2009): Seasonal variations in physico-chemical parameters of water and sediment characteristics of Pondicherry mangroves. - African Journal of Basic and Applied Sciences 1(1-2): 36-43.

[49] Schmidt, M. W. I., Torn, M. S., Abiven, S., Dittmar, T., Guggenberger, G., Janssens, I. A., Kleber, M., Kögel-Knabner, I., Lehmann, J., Manning, D. A. C., Nannipieri, P., Rasse, D. P., Weiner, S., Trumbore, S. E. (2011): Persistence of soil organic matter as an ecosystem property. - Nature 478: 49-56.

[50] Sitoe, A., Mandlate, L., Guedes, B. (2014): Biomass and carbon stocks of Sofala bay mangrove forests. - Forests 5(8): 1967-1981.

[51] Vázquez-Lule, A., Colditz, R., Herrera-Silveira, J., Guevara, M., Rodríguez-Zúñiga, M. T., Cruz, I., Vargas, R. (2019): Greenness trends and carbon stocks of mangroves across Mexico. - Environmental Research Letters 14(7): 075010.

[52] Xue, Z., An, S. (2018): Changes in soil organic carbon and total nitrogen in a small hydrographic basin scale as a result of the conversion of land use on the Loess Plateau. Sustainability 10(12): 4757.

[53] Yimer, F., Ledin, S., Abdelkair, A. (2006): Soil organic carbon and total nitrogen stocks affected by topographic aspect and vegetation in the Bale Mountains, Ethiopia. - Geoderma 135: 335-344.

[54] Zar, J. H. (2010): Biostatistical Analysis. - 5th Edition. Pearson Prentice-Hall, Upper Saddle River, NJ.

[55] Zinn, Y. L., Lal, R., Resck, D. V. S. (2005): Changes in soil organic carbon stocks under agriculture in Brazil. - Soil Till. Res. 84: 28-40. 